Original article

\title{
A study on knowledge and self-care practices about Diabetes Mellitus among patients with type 2 Diabetes Mellitus attending selected tertiary healthcare facilities in coastal Karnataka
}

\author{
Anjali Shrivastva $^{\mathrm{a}}$, Sameer Phadnis ${ }^{\mathrm{a}, *}$, Karthik Rao $\mathrm{N}^{\mathrm{b}}$, Manisha Gore ${ }^{\mathrm{c}}$ \\ ${ }^{a}$ Department of Public Health, Manipal University, Manipal, 576104, Karnataka, India \\ ${ }^{\mathrm{b}}$ Department of Medicine, Dr. TMA Pai Rotary Hospital, Karkala, 574104, India \\ ${ }^{\mathrm{c}}$ Symbiosis Institute of Health Sciences, Symbiosis International University, Lavale, Mulshi, Pune, Maharashtra, 412115, India
}

A R T I C L E I N F O

\section{Keywords:}

Knowledge

Self-care practices

Type 2 Diabetes Mellitus

Diabetes Mellitus

\begin{abstract}
A B S T R A C T
Objective: To assess knowledge and self-care practices about Diabetes among patients with type 2 Diabetes Mellitus attending selected tertiary health care institutions.

Methods: Cross-sectional study was conducted to assess the knowledge and self-care practices about Diabetes among diagnosed Type 2 Diabetes Mellitus patients attending the out-patient facilities of Medicine Department at selected tertiary healthcare institutions of Udupi Taluk. The data collection occurred from January to March 2017. A total of 166 participants were included in the study and they were selected using consecutive sampling. Knowledge about Diabetes Mellitus was assessed using structured pre-tested questionnaire. Diabetes SelfManagement Questionnaire-Revised version was used to assess self-care practices regarding Diabetes Mellitus. Results: Most of the participants ( $>65 \%$ ) had knowledge about different aspects of Diabetes. The Mean total score of self-care practices among participants without and with intensive insulin treatment was 6.25 $\pm 1.25 \mathrm{SD}$ and $6.20 \pm 1.01 \mathrm{SD}$ respectively. Mean subscales score related to dietary control, glucose management and physician contact was almost the same as that of total mean scale score except for physical activity subscale score in both the group of patients.

Conclusion: This study emphasizes the need to strengthen the initiatives related to generating awareness about diabetes and improving self-care practices related to it.
\end{abstract}

\section{Introduction}

Diabetes is a chronic disease marked by high blood sugar level resulting from lack of either insulin (a hormone that regulates blood glucose) production, insulin action, or both. ${ }^{1}$ Diabetes can lead to premature deaths as well as serious complications and disabilities. ${ }^{2}$ As per the Diabetes Atlas published by the IDF (International Diabetes Federation) in the year 2011, the adjusted prevalence rate of Diabetes worldwide was $8.3 \%$ which is expected to rise to $9.9 \%$ by the year 2030. Similarly, India would see an increase in prevalence of Diabetes from $9 \%$ to $10.6 \%$ during the same time period. ${ }^{3}$ The prevalence of Type 2 Diabetes Mellitus is showing a rising trend among developing countries like India because of myriad socio-demographic, political and economic influences. ${ }^{4}$ India has been dubbed as the "Diabetes Capital of the World" as it is home to largest number of patients with Type 2 Diabetes Mellitus in the world. ${ }^{5}$ The direct cost related to management of Diabetes in India has almost doubled between the years 1998-2005. ${ }^{6}$ Studies have shown that awareness about Diabetes Mellitus and following the recommended self-care practices for it , are the mainstay of controlling Diabetes Mellitus and its complications. ${ }^{7}$ Furthermore, research has shown that non-adherence to prescribed self-care practices for Diabetes is associated with adverse outcomes like decreased quality of life and reduced life expectancy. ${ }^{8,9}$ Considering the above, present study was conducted to assess the knowledge and self-care practices about Diabetes Mellitus among patients with Type 2 Diabetes Mellitus attending selected tertiary healthcare facilities in Udupi taluka of Karnataka state.

\section{Materials and methods}

The present study was a cross-sectional study conducted among diagnosed Type 2 Diabetes Mellitus patients coming for follow up at

\footnotetext{
* Corresponding author.

E-mail addresses: anjalishrivastva@gmail.com (A. Shrivastva), drphadnis78@gmail.com (S. Phadnis), karthikrao85@gmail.com (K. Rao N), manishagr755@gmail.com (M. Gore).
} 
out-patient Department (O.P.D) of Medicine department in selected tertiary healthcare facilities (Kasturba Medical College, Manipal: a teaching hospital and District Hospital, Udupi) in Udupi Taluk from January to March 2017. The inclusion criteria adopted for the study was that the study subject should be an adult, ambulatory, diagnosed with disease at-least one year before the study began possesing a medical record and attending the outpatient department of Department of Medicine at selected tertiary healthcare institutions in Udupi taluk. Exclusion criteria were: Type 2 Diabetes Mellitus patients who were seriously ill or bed ridden and those who refused to give their consent to participate in the study. The total number of subjects included in the study was 166 and they were selected using consecutive sampling. A structured questionnaire was used for collecting information from the participants about socio-demographic characteristics of the respondents and their knowledge about Diabetes through face to face interview. Awareness of study participants about what is Diabetes Mellitus; the cutoff of blood sugar level (BSL) for diagnosis of Diabetes Mellitus, it's symptoms, complications of Diabetes Mellitus, foot care for Diabetes, role of diet and exercise in Diabetes, role of stress in Diabetes and role of medication in Diabetes was assessed. In this study self-care practices for the Type-2 Diabetic patients was defined as adherence to prescribed guidelines related to diet, physical activity, self-monitoring of BSL, foot care, adherence to the prescribed anti-diabetic medications or insulin use. ${ }^{10}$ Self-care practices related to Diabetes Mellitus were assessed using DSMQ-R (Diabetes Self-Management Questionnaire-Revised) scale. This tool comprises of total 27 items for patients recieving intensive Insulin therapy and 20 items for patients not recieving intensive Insulin treatment. The items are distributed into four subscales which are (i) Dietary Control (DC) sub-scale (ii) Glucose Management (GM) sub-scale (iii) Physical Activity (PA) sub-scale and (iv) Physician Contact (PC) sub-scale. This individual subscales scores are combined to find the total sum scale score. Both the individual subscale scores as well as the total sum scale score vary between 0 and 10 . Higher score on a subscale or sum scale indicates that patient is more adherent to selfcare practices for Diabetes Mellitus as compared to patient with lower score on the scale. ${ }^{11}$

Ethics approval was obtained from the Institutional Ethics Committee, Manipal University and Kasturba Hospital Ethics Committee, Manipal. The data was collected after taking the informed consent from the participants. The data collected were analyzed using SPSS version 16. Frequency and percentages were tabulated for the socio-demographic characteristics and knowledge about different aspects of Type 2 Diabetes. Also, mean and standard deviation (SD) of total sum scale and sub-scale score for DSMQ-R tool were computed.

\section{Results}

In the present study, the gender wise distribution of study subjects was $65.7 \%$ males and $34.3 \%$ females. The age group to which most of the subjects belonged was between 49 and 68 years and $97 \%$ of the participants were married. In this study, majority of the respondents (55.4\%) were unemployed which included retired people or housewives and $21.7 \%$ respondents belonged to category clerk, shop owner and farmer. Most of the study subjects had received education up to high-school and above and only $6(3.6 \%)$ among all were found illiterate (Table 1). About knowledge aspect of Diabetes, this study found that majority of the participants $(80 \%)$ knew about the various symptoms of Diabetes. In this study, about $72 \%$ respondents knew the consequences if the disease is not treated. More than $70 \%$ of them were aware about complications of Diabetes i.e body parts or organs that Diabetes can affect. According to this study about $70 \%$ of the respondents knew about how to deal with cuts and abrasions in foot in other words about footcare in Diabetes. Also, about $65 \%$ of the respondents were aware of the role of diet and exercise in Diabetes. However, only $25.9 \%$ of respondents were able to explain "what is Diabetes", $16.3 \%$ of the participants were aware that they were actually
Table 1

Table showing the Socio-Demographic characteristics of the respondents.

\begin{tabular}{|c|c|c|c|}
\hline $\begin{array}{l}\text { Socio-Demographic } \\
\text { Characteristic }\end{array}$ & Category & Frequency & Percentage (\%) \\
\hline \multirow[t]{3}{*}{ Gender } & Male & 109 & 65.7 \\
\hline & Female & 57 & 34.3 \\
\hline & Total & 166 & 100 \\
\hline \multirow[t]{8}{*}{ Age (in complete years) } & $19-28$ & 0 & 0 \\
\hline & $29-38$ & 6 & 3.6 \\
\hline & $39-48$ & 31 & 18.7 \\
\hline & $49-58$ & 49 & 29.5 \\
\hline & $59-68$ & 48 & 28.9 \\
\hline & $69-78$ & 27 & 16.3 \\
\hline & 79 and above & 5 & 3.0 \\
\hline & Total & 166 & 100 \\
\hline \multirow[t]{5}{*}{ Marital status } & Single & 4 & 2.4 \\
\hline & Married & 161 & 97.0 \\
\hline & Divorced & 1 & 0.6 \\
\hline & Widowed & 0 & 0 \\
\hline & Total & 166 & 100 \\
\hline \multirow[t]{8}{*}{ Occupation } & $\begin{array}{l}\text { Unemployed } \\
\text { (Housewife/Retired) }\end{array}$ & 92 & 55.4 \\
\hline & Professional & 9 & 5.4 \\
\hline & Semi-professional & 2 & 1.2 \\
\hline & $\begin{array}{l}\text { Clerk, Shop owner, } \\
\text { Farmer }\end{array}$ & 36 & 21.7 \\
\hline & Skilled worker & 8 & 4.8 \\
\hline & Semi-skilled worker & 10 & 6.1 \\
\hline & Unskilled worker & 9 & 5.4 \\
\hline & Total & 166 & 100 \\
\hline \multirow[t]{6}{*}{ Educational Qualification } & Primary & 38 & 22.9 \\
\hline & High-school & 55 & 33.1 \\
\hline & Pre-university & 26 & 15.7 \\
\hline & Graduate \& above & 41 & 24.7 \\
\hline & Illiterate & 6 & 3.6 \\
\hline & Total & 166 & 100 \\
\hline
\end{tabular}

Table 2

Table showing the knowledge of participants regarding different aspects of Diabetes.

\begin{tabular}{|c|c|c|c|}
\hline Awareness about what is Diabetes & Category & Frequency & Percentage (\%) \\
\hline & Know & 43 & 25.9 \\
\hline & Don't know & 123 & 74.1 \\
\hline \multirow{2}{*}{$\begin{array}{l}\text { Awareness about cutoff of blood } \\
\text { sugar level for a person to be } \\
\text { considered as diabetic. }\end{array}$} & Know & 17 & 10.2 \\
\hline & Don't Know & 149 & 89.8 \\
\hline \multirow{4}{*}{$\begin{array}{l}\text { Awareness about the type of } \\
\text { Diabetes respondent is suffering } \\
\text { from. }\end{array}$} & Type-1 & 9 & 5.4 \\
\hline & Type-2 & 27 & 16.3 \\
\hline & Gestational & 0 & 0 \\
\hline & Don't Know & 130 & 78.3 \\
\hline \multirow{2}{*}{$\begin{array}{l}\text { Awareness about symptoms of } \\
\text { Diabetes. }\end{array}$} & Know & 134 & 80.7 \\
\hline & Don't Know & 32 & 19.3 \\
\hline \multirow{2}{*}{$\begin{array}{l}\text { Awareness about receiving } \\
\text { instruction from physician about } \\
\text { Diabetes care. }\end{array}$} & Yes & 158 & 95.2 \\
\hline & No & 8 & 4.8 \\
\hline \multirow{2}{*}{$\begin{array}{l}\text { Awareness about role of Diet in } \\
\text { Diabetes }\end{array}$} & Know & 114 & 68.7 \\
\hline & Don't Know & 52 & 31.3 \\
\hline \multirow{2}{*}{$\begin{array}{l}\text { Awareness about role of Exercise in } \\
\text { Diabetes. }\end{array}$} & Know & 107 & 64.5 \\
\hline & Don't Know & 59 & 35.5 \\
\hline \multirow{2}{*}{$\begin{array}{l}\text { Awareness about consequences if } \\
\text { Diabetes is not treated. }\end{array}$} & Know & 119 & 71.7 \\
\hline & Don't Know & 47 & 28.3 \\
\hline \multirow{2}{*}{$\begin{array}{l}\text { Awareness about role of Medications } \\
\text { (drugs/insulin) in Diabetes. }\end{array}$} & Know & 133 & 80.1 \\
\hline & Don't Know & 33 & 19.9 \\
\hline \multirow{2}{*}{$\begin{array}{l}\text { Awareness about role of Stress in } \\
\text { Diabetes. }\end{array}$} & Know & 128 & 77.1 \\
\hline & Don't Know & 38 & 22.9 \\
\hline \multirow{2}{*}{$\begin{array}{l}\text { Awareness about how to deal with } \\
\text { cuts and abrasions in Diabetes } \\
\text { (Foot care) }\end{array}$} & Know & 116 & 69.9 \\
\hline & Don't Know & 50 & 30.1 \\
\hline \multirow{3}{*}{$\begin{array}{l}\text { Awareness of the body parts or } \\
\text { organs that Diabetes can affect. } \\
\text { Total }\end{array}$} & Know & 126 & 75.9 \\
\hline & Don't Know & 40 & 24.1 \\
\hline & & 166 & 100 \\
\hline
\end{tabular}


Table 3

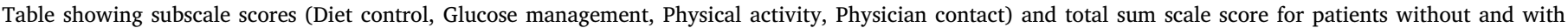
intensive insulin treatment.

\begin{tabular}{|c|c|c|c|c|c|}
\hline $\begin{array}{l}\text { Patients without intensive insulin } \\
\text { treatment }\end{array}$ & Diet scale score & $\begin{array}{l}\text { Glucose management scale } \\
\text { score }\end{array}$ & $\begin{array}{l}\text { Physical activity scale } \\
\text { score }\end{array}$ & $\begin{array}{l}\text { Physician contact scale } \\
\text { score }\end{array}$ & Total scale score of 20 items \\
\hline Total number of respondents & 166 & 166 & 166 & 166 & 166 \\
\hline Mean & 6.6432 & 6.9799 & 4.9331 & 6.5110 & 6.2500 \\
\hline Std. Deviation & \pm 1.92484 & \pm 1.79888 & \pm 2.80144 & \pm 1.53962 & \pm 1.24624 \\
\hline $\begin{array}{l}\text { Patients with intensive insulin } \\
\text { treatment }\end{array}$ & Diet scale score & $\begin{array}{l}\text { Glucose management scale } \\
\text { score }\end{array}$ & $\begin{array}{l}\text { Physical activity scale } \\
\text { score }\end{array}$ & $\begin{array}{l}\text { Physician contact scale } \\
\text { score }\end{array}$ & $\begin{array}{l}\text { Total scale score of } 27 \\
\text { items }\end{array}$ \\
\hline Total number of respondents & 166 & 47 & 166 & 166 & 47 \\
\hline Mean & 6.6432 & 6.3298 & 4.9331 & 6.5110 & 6.2017 \\
\hline Std. Deviation & \pm 1.92484 & \pm 1.38639 & \pm 2.80144 & \pm 1.53962 & \pm 1.00831 \\
\hline
\end{tabular}

suffering from Type2 Diabetes. The percentage of subjects aware about the cutoff of blood sugar level for diagnosis of Diabetes was 10.2 (Table 2). The mean total sum scale score of DSMQ-R tool for self-care practices among participants without intensive insulin treatment was $6.25 \pm 1.25 \mathrm{SD}$ and $6.20 \pm 1.01 \mathrm{SD}$ for participants on intensive insulin therapy. This study found that mean subscale score related to Dietary Control, Glucose Management and Physician Contact was almost the same as that of total sum scale score except for the Physical Activity subscale score. The Physical Activity subscale score was lower than total sum scale and other sub-scale scores (Table 3).

\section{Discussion}

In the present study, about $65 \%$ of respondents had knowledge about the role of diet and exercise in Diabetes. These findings agree with the results of studies conducted by Shrivastava et al. and Padma et al. ${ }^{12,13}$ In this study, more than $70 \%$ study subjects knew about the complications of Diabetes. Similar findings were reported by a study done by Kurian et al. ${ }^{14}$

In this study, sum scale score for Diabetes self-care practice was almost same in patients with and without intensive insulin therapy. This score was $6.25 \pm 1.24$ and $6.20 \pm 1.01$ for patients with and without intensive insulin therapy. The individual mean subscale scores related to Dietary Control, Glucose Management and Physician Contact sub-scales were almost same and sub-scale score for Physical Activity was lower than other sub-scale scores. A study done by Hammad et al. among patients with Type 2 Diabetes in Jordan found a similar sum scale score and lower score on Physical Activity subscale as compared to other subscale scores. ${ }^{15}$ This finding was quite different from the findings of study conducted by Mehravar et al., where similar tool was used in which they found that mean subscale score of Glucose Management and Dietary Control sub-scale were same as sum scale score mean whereas Physical Activity and Physician Contact sub-scale score were lower then sum scale score. ${ }^{16}$

The strength of the study is that it used a standardized tool to compare self-care practices among patients with Type 2 Diabetes Mellitus on intensive Insulin therapy with those not on intensive Insulin therapy and it points towards themes that awareness campaigns on Type-2 Diabetes in India need to focus on. However, limitation of this study was that the HbA1c level of the patients with Type 2 Diabetes was not assessed due to resource constraints, this could have been correlated with self-care practices about Diabetes Mellitus.

\section{Conclusion}

This study points towards the need for initiatives for improving selfcare practices among patients with Type 2 Diabetes Mellitus in India and use of standardized tools like DSMQ-R for the assessment of the same. The awareness campaigns for Diabetes Mellitus should focus on informational needs of the patients with Type 2 Diabetes and this study points towards the informational gaps which should be addressed by Diabetes prevention interventions.

\section{Funding}

This research did not receive any specific grant from funding agencies in the public, commercial, or not-for-profit sectors.

\section{Declaration of competing interest}

Declarations of interest: none.

\section{Acknowledgements}

The authors would like to thank patients with Type 2 Diabetes who participated in the study, Professor\& Head of Department of Medicine of Kasturba Medical College Hospital, Manipal and Head of the concerned unit of Medicine Department at District Hospital, Udupi for their cooperation and good wishes.

\section{References}

1. World Health Organisation. Definition, Diagnosis, and Classification of Diabetes Mellitus and its Complications: Report of a WHO Consulation. Geneva: World Health Organisation; 1999.

2. World Health Organization. reportGlobal Report on Diabetes.

3. Whiting DR, Guariguata L, Weil C, Shaw J. IDF Diabetes Atlas: global estimates of the prevalence of diabetes for 2011 and 2030. Diabetes Res Clin Pract. 2011;94(3):311-321. https://doi.org/10.1016/j.diabres.2011.10.029. Available from:

4. Ramachandran A, Snehalatha C, Viswanathan V. Burden of Type 2 Diabetes and its Complications - the Indian Scenario. 2001; 2001 (May 2014).

5. Gupta V, Suri P. Diabetes in elderly patients. JK Pract. 2002;9(4):258-259.

6. Ramachandran A, Ramachandran S, Snehalatha C, et al. Increasing expenditure on health care incurred by diabetic subjects in a developing country: a study from India. Diabetes Care. 2007;30(2):252-256.

7. Heisler M, Piette JD, Spencer M, Kieffer E, Vijan S. The relationship between knowledge of recent HbA1c values and diabetes care understanding and self-management. Diabetes Care. 2005;28(4):816-822

8. Saleh F, Mumu SJ, Ara F, Hafez A, Ali L. Non-adherence to Self-Care Practices \& Medication and Health Related Quality of Life Among Patients with Type 2 Diabetes : A Cross-Sectional Study. vols. 1-8. 2014; 2014.

9. The Impact of Treatment Noncompliance. 2012; 2012 (July 2011).

10. Tewahido D, Berhane Y. Self-care practices among diabetes patients in Addis Ababa : A Qualitative Study. 2017;1-10

11. Schmitt A, Gahr A, Hermanns N, Kulzer B, Huber J, Haak T. The Diabetes SelfManagement Questionnaire (DSMQ): development and evaluation of an instrument to assess diabetes self-care activities associated with glycaemic control. Health Qual Life Outcomes. 2013;11(1):138 [Internet]. http://www.hqlo.com/content/11/1/ 138\%5Cnhttp://www.pubmedcentral.nih.gov/articlerender.fcgi? $\operatorname{artid}=3751743 \&$ tool $=$ pmcentrez\&rendertype $=$ abstract.

12. Shrivastava PS, Ram S, Lal B, Ramasamy J. An Epidemiological Study to Assess the Knowledge and Self Care Practices Among Type 2 Diabetes Mellitus Patients Residing in Rural Areas of Tamil Nadu. vols. 2-5. 2015; 2015.

13. Padma K, Bele S, Bodhare T. Evaluation of knowledge and self care practices in diabetic patients and their role in disease management. Natl J Res Community Med. 2012;3(1):3-6.

14. Kurian B, Qurieshi MA, Ganesh R, Leelamoni K. A community-based study on 
knowledge of diabetes mellitus among adults in a rural population of Kerala introduction. 2019; 2019:59-64 2.

15. Hammad S, Darawad M, Hourani E, Demeh W. Predictors of glycated hemoglobin among jordanian diabetic patients. Iran J Public Health. 2015;44(11):1482-1491.

16. Mehravar F, Mansournia MA, Holakouie-Naieni K, Nasli-Esfahani E, Mansournia N,
Almasi-Hashiani A. Associations between Diabetes Self-Management and Microvascular Complications in Patients with Type 2 Diabetes. vol. 38. 2016; $2016 \mathrm{e} 2016004$

Epidemiol Health [Internet]. http://www.ncbi.nlm.nih.gov/pubmed/26883737\%

5Cnhttp://www.pubmedcentral.nih.gov/articlerender.fcgi?artid = PMC4789607. 